\title{
Emplacement characteristics of Late Cretaceous and Paleocene pyroclastic and injected kimberlites in northern Alberta, Canada
}

\author{
D.R. Eccles ${ }^{1}$, A.R. Sweet ${ }^{2}$, R.A. Creaser ${ }^{3}$, L.M. Heaman ${ }^{3}$ and K. Boyce ${ }^{2}$ \\ ${ }^{I}$ Energy Resource Conservation Board, Alberta Geological Survey, Edmonton, Canada \\ ${ }^{2}$ Natural Resources Canada, Geological Survey of Canada, Calgary, Canada \\ ${ }^{3}$ Department of Earth \& Atmospheric Sciences, University of Alberta, Edmonton, Canada
}

\begin{abstract}
Introduction
The preservation of kimberlite in the Western Canadian Sedimentary Basin, hereafter referred to as WCSB-type kimberlite, allows us to study the uppermost portion of kimberlite bodies that are sheared off or eroded away in many other parts of the world. Kimberlite-host rock chronological and petrological studies in the diamondiferous Buffalo Head Hills kimberlite field of north-central Alberta facilitate new interpretation on the timing and distribution of magmatism in the WCSB-type kimberlite setting.
\end{abstract}

Based on radiogenic isotope, palynological and petrological results, three different emplacement settings are recognized: Paleocene ultramafic volcanism that is eroded to present day stratigraphic levels, Late Cretaceous syndepositional volcanism, and Paleocene and Late Cretaceous interstratal dykes and sills that collectively define a kimberlite field characterized by tabular, often stacked kimberlite layers of varying ages. Correlations between emplacement style, body morphology, diamond content, spatial distribution and rock classification have important consequences for geological modeling critical for resource evaluation and consideration for future diamond exploration in other parts of the WCSB.

\section{Background and Supplementary Data}

Ultramafic rocks occur in three separate areas of the northern Alberta kimberlite province (Eccles et al., 2004). The Buffalo Head Hills kimberlite field, which is the focus of this study, has received the most attention because of large geophysically-inferred kimberlite dimensions (up to 45 ha), potential economic grades (up to 55 carats per hundred tonnes; K252 kimberlite) and a high ratio of diamondiferous to barren kimberlite (28 of the 40 occurrences contain diamonds).

Examination of 53 drill cores drilled by Ashton Mining of Canada Inc. (now Stornoway Resources Ltd.) from 21 separate Buffalo Head Hills bodies provided sample material for two separate, but collaborative studies to understand kimberlite-host rock relationships of the kimberlite field. Sweet et al. (in prep.) assembled a continuous Late Cretaceous to Paleocene bedrock section that spans vertically over $560 \mathrm{~m}$ to determine chronostratigraphic correlations between sedimentary basin configurations and kimberlite emplacement. Eccles et al. (2008) examined kimberlite cores for fresh macroscopic phlogopite and groundmass perovskite and reported robust $\mathrm{Rb}-\mathrm{Sr}$ and $\mathrm{U}-\mathrm{Pb}$ age determinations, respectively, for 12 bodies. Both studies span the geographic extent of the Buffalo Head Hills field and included barren and diamondiferous bodies.

The radiogenic and palynological studies reported two distinctive events: coeval Turonian to Campanian ( 88-81 Ma) volcanism-sedimentation and a younger Paleocene-aged ( 64-60 Ma) eruptive event (Fig. 1).

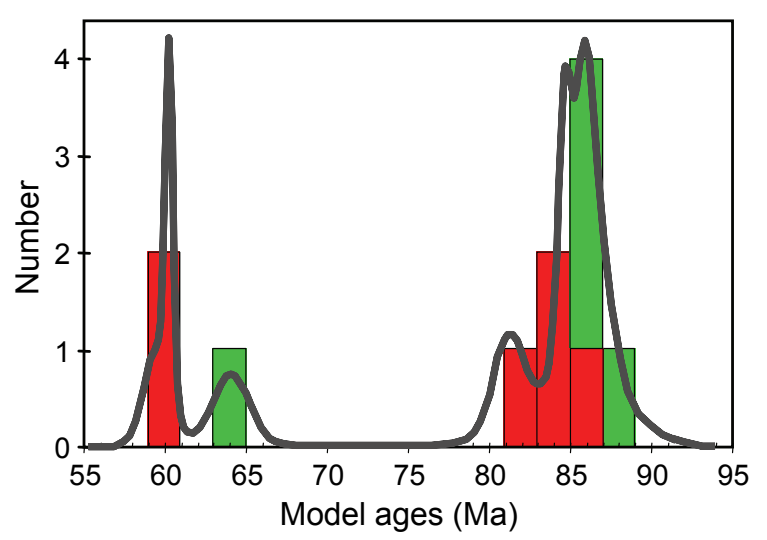

Fig. 1. Cumulative probability diagram of phlogopite $\mathrm{Rb}-\mathrm{Sr}$ (red) and perovskite U-Pb model ages (green) for selected ultramafic rocks from the Buffalo Head Hills kimberlite field.

Nine kimberlites yield Late Cretaceous ages between $88 \pm 5 \mathrm{Ma}$ (U-Pb perovskite, K5A kimberlite) and 81.2 $\pm 2.3 \mathrm{Ma}$ (Rb-Sr phlogopite, K252 kimberlite). A Danian U-Pb perovskite isochron age of $63.5 \pm 0.7 \mathrm{Ma}$ was obtained for the BM2 kimberlite, and Paleocene $\mathrm{Rb}-\mathrm{Sr}$ ages of $59.6 \pm 2.8 \mathrm{Ma}$ and $60.3 \pm 0.8 \mathrm{Ma}$ were determined for the K1A and K19 bodies, respectively. Radiogenic ages are supported by palynological interpretation. Sedimentary clasts incorporated in the $\sim 60 \mathrm{Ma}$ ultramafic bodies include Maastrichtian and Paleocene miospores, and Turonian to Santonian host mudstone strata are contemporaneous with the $\sim 88-81$ 
Ma kimberlite suite. Chronostratigraphic correlations between sedimentary basin configurations and kimberlite emplacement are also evident. For example, a sedimentological hiatus with a maximum extent of Early Turonian through to possibly Campanian, spans 90-81 Ma ages and suggests kimberlite emplacement might be related to extensional tectonism and uplift in the Buffalo Head Hills area.

\section{Paleocene Ultramafics-Subsequently Truncated}

The youngest eruptive event is of Paleocene age ( $\sim 64-$ $60 \mathrm{Ma}$ ) whereas the youngest preserved host rocks capping the Buffalo Head Hills are of Campanian age. In this instance the only record of now eroded latest Campanian through Paleocene host rocks is from sedimentary xenoliths in the preserved part of the truncated intra-crater facies kimberlite (e.g., K1A and K1B kimberlites). The extent of truncation can be estimated to be about $500 \mathrm{~m}$ based on comparison with a more complete stratigraphic section in central Alberta. The miospore assemblages in the sedimentary xenoliths indicate a terrestrial depositional environment at the time of eruption. Other sedimentary xenoliths and the surrounding preserved host rocks record the older pre-eruptive strata.

The $\sim 60$ Ma bodies occur in the southwestern part of the field and are either barren or have poor diamond content (Fig 2). The K1 and K19 bodies have minerals (e.g., edenite-pargasite) and geochemical compositions (e.g., REE patterns) that differ from archetypal kimberlite and bona-fide Cretaceous kimberlite in the northwestern part of the field. Their similarity to ultrabasic bodies in other parts of northern Alberta (Mountain Lake cluster and Xena occurrence in the Birch Mountains field) enticed Eccles et al. (2008) to conclude that these rocks are better referred to as either hybrid or non-kimberlite ultramafic rocks.

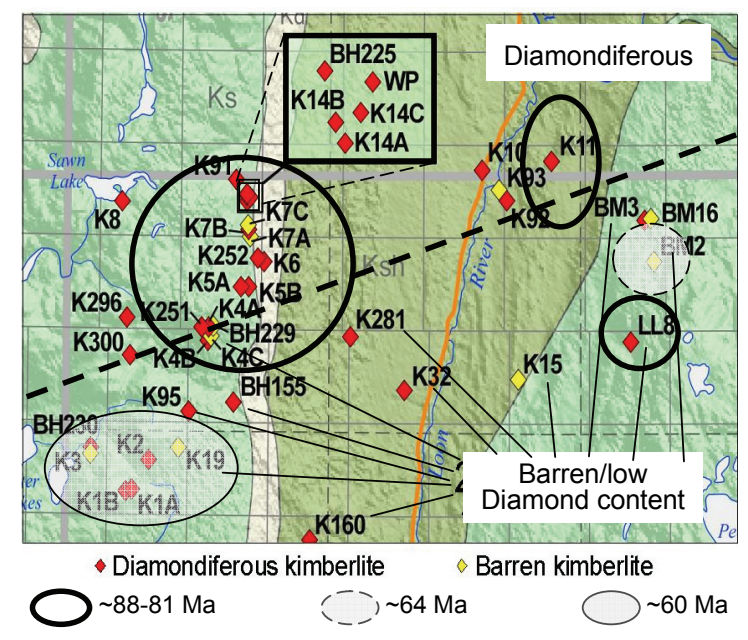

Fig. 2. Spatial location of $\sim 88-81 \mathrm{Ma}, \sim 64 \mathrm{Ma}$ and $\sim 60$ Ma ultramafic rocks in the Buffalo Head Hills kimberlite field. The dashed northeasterly-trending line separates the field into two parts: the diamondiferous northern part and barren to low diamond content southern part.

\section{Late Cretaceous Syndepositional Volcanism}

A suite of 88-81 Ma kimberlites appear to be emplaced coevally with the host strata although the term syndepositional is tenuous because an extensive Turonian (in part or in whole) through Early Campanian hiatus coincides with kimberlite emplacement (Fig. 3). These kimberlites are either covered by post-event Santonian and Campanian strata or exhumed to outcrop or subcrop beneath glacial tills. It is probable that they erupted onto a Late Cretaceous landscape that was later transgressed by marine waters.

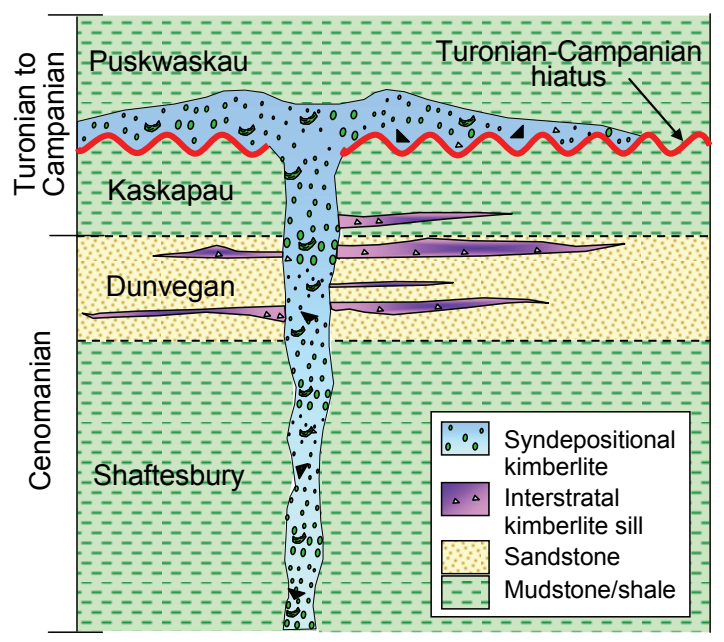

Fig. 3. Cartoon to depict complex relationships between syndepositional and interstratal kimberlite.

The $\sim 88-81$ Ma volcanic rocks are bona fide kimberlite (Eccles et al. 2008), the majority of which are located in the northwestern part of the field and correspond to the northern group of diamondiferous bodies. Thus, an important conclusion is that the 'diamond window' in this kimberlite field is prevalent at $\sim 88-81 \mathrm{Ma}$.

A favourable consequence of syndepositional emplacement to diamond explorers is the potential for large near surface deposits, albeit morphologically complex. Given this scenario, crater-facies kimberlite of this age could cover vast areas, such that some component of the 40 reported individual occurrences of kimberlite might be, to some degree, inter-related. For this reason, the majority of the kimberlites in this field should be referred to as occurrences or bodies, and designation as 'pipes' should be reserved until proven through advanced exploration/exploitation.

Paleocene-Late Cretaceous Interstratal Volcanism The third style of emplacement is interstratal. In the BM2 kimberlite, Lower Paleocene ( $\sim 64$ Ma) hypabyssal kimberlite is intrusive into thermally enhanced Campanian through Albian host rocks. The character and age of the kimberlite and the thermal enhancement of the host rock form a cohesive story. 
A second example of interstratal emplacement is more enigmatic. The Campanian K252 kimberlite (81.3 \pm 2.3 $\mathrm{Ma} \mathrm{Rb}-\mathrm{Sr}$ phlogopite; Eccles et al., 2008), which has previously been described as having pyroclastic textures (Boyer 2005), is intruded into Cenomanian and Albian aged strata. This conundrum cannot be explained by faulting because palynological determinations record older sedimentary rocks both below and above layers of kimberlite. An unknown older eruption event remains a possibility, but investigation of 2008 K252 drill cores, drilled by Diamondex Resources Ltd. and Shore Gold Inc., leads us to suggest that the pyroclastic rocks represent kimberlite sills injected into and/or directly adjacent to non-marine clastic wedges representative of major sea level low stands in the WCSB (e.g., Fig. 3).

The K252 kimberlite is composed of an alternating sequence of kimberlite and mudstone with most drill holes ending at approximately $200 \mathrm{~m}$ depth in kimberlite, bituminous-rich sandstone or a mixture of both. Evidence of magmatic-sedimentary rock interaction is observed at both the bottom and top kimberlite-mudstone contacts, particularly in lower parts of the K252 kimberlite core (Fig. 4). Blocky and fluidal peperitic textures include: kimberlite-mudstone mingling \pm clasts of mudstone and kimberlite, hydrothermal alteration, jigsaw in situ fragmentation and fines-depleted elutriation features. Sedimentary rocks adjacent to the kimberlite contact are massive, display fluid-fluid shear, stratification discordant to the predominant stratification of clastic rocks in the area and are sometimes mineralized. Competent kimberlite adjacent to basal kimberlite-mudstone contacts displays various textures including those supportive to sill emplacement such as macrocrystal olivine-rich kimberlite breccia and globular juvenile clasts with mudstone nuclei. These observations provide physical evidence compliant with the radiogenic-palynological hypothesis of injection of younger magma into older stratigraphy.

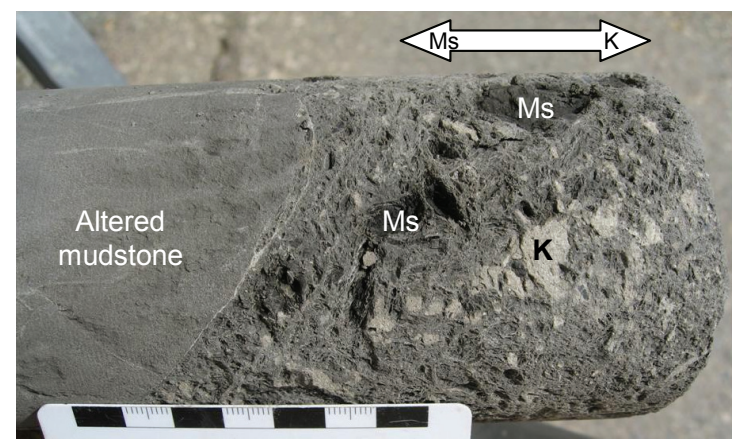

Fig. 4. Peperite - or kimberlite and mudstone mingling with clasts of mudstone and kimberlite - at upper kimberlite-mudstone contact. Double arrow shows the direction of competent mudstone and kimberlite. Clast abbreviations: Ms - mudstone; $\mathrm{K}$ - kimberlite.

\section{WCSB-Type Kimberlite Model: Implications}

This new model of WCSB-type kimberlite emplacement - defined by stacked kimberlite complexes that can include multiple mechanisms of emplacement such as syndepositional pyroclastic kimberlite and intrusive kimberite sills-has implications for future geological modeling and resource calculation. The inferred dimensions of the Buffalo Head Hills kimberlite bodies, which are currently inferred by the extent of their individual geophysical profiles, have the potential to be much larger, both laterally and vertically based on the complex inter-relationship of the various mechanisms of emplacement proposed in this study. In addition, knowledge and separation of sydepositional and interstratal kimberlites may benefit future diamond evaluation, particularly because new radiogenic results show that several of the Buffalo Head Hills bodies with high diamond content have similar $\sim 81 \mathrm{Ma} \mathrm{Rb}-\mathrm{Sr}$ phlogopite ages as the K252 kimberlite.

With respect to modelling, future core documentation of kimberlite in the WCSB should consider the interstratal textures and kimberlite-host rock contacts described in this work. Discordant sediment stratification, kimberlite-mudstone mixing and other textures associated with the injected sills could be confused with pyroclastic textures (e.g., base surge deposits).

Finally, there is an apparent relationship between WCSB-type kimberlite volcanism and diachronous non-marine sandy clastic wedges, which are known to occur at various stratigraphic levels and often extend throughout the WCSB. For example, the Buffalo Head Hills and Fort à la Corne kimberlite fields are hosted stratigraphically within Cenomanian Dunvegan Formation in north-central Alberta and Albian Cantuar and Pense formations in central Saskatchewan, respectively. We postulate that the sandstone horizons provide pathways of least resistance for the injection of younger kimberlite magma (kimberlite sills).

\section{References}

Boyer, L.P. 2005. Kimberlite volcanic facies and eruption in the Buffalo Head Hills, Alberta. M.Sc. thesis. Mineral Deposit Research Unit, University of British Columbia.

Eccles, D.R., Heaman, L.M., Luth, R.W., Creaser, R.A. 2004. Petrogenesis of the Late Cretaceous northern Alberta kimberlite province. Lithos, 77 (1), 435-459.

Eccles, D.R., Creaser, R.A., Heaman, L.M., Ward, J. 2008 $\mathrm{Rb}-\mathrm{Sr}$ and $\mathrm{U}-\mathrm{Pb}$ geochronology and getting of the Buffalo Head Hills kimberlite field, northern Alberta. Canadian Journal of Earth Sciences, 45 (5),

Sweet, A.R., Boyce, K., Eccles, D.R. In prep. Palynological constraints on kimberlite emplacement models: chronostratigraphy of host rock and clastic xenoliths, Buffalo Head Hills, Alberta. 